\title{
Occurrence of scheelite in the early Archaean Isua supracrustal belt, West Greenland
}

\author{
Peter W. Uitterdijk Appel
}

As part of the regional stream sediment sampling programme in the Godthåb area (Appel, 1983, 1984), 22 stream sediment samples were collected in the Isukasia area in 1983, of which 21 appeared to contain scheelite. In 1984 a one-week field programme was carried out towards the end of August in order to find in situ scheelite within the Isua supracrustal rocks.

The following brief report is based on field observations only; laboratory work has been confined to X-ray identification of scheelite in three stream sediment samples and in three rock samples.

\section{General geology}

The geology of the Isua supracrustal belt has recently been described by Nutman et al. (1983), and the mineralisations have been described by Appel $(1979,1980)$.

Despite the age of $3800 \mathrm{~m} . \mathrm{y}$., the Isua supracrustal belt exhibits a lithology very similar to younger supracrustal belts elsewhere. The main units comprise layered and massive amphibolites as well as carbonate-bearing siliceous schists (fig. 16), presumably representing basic and acid volcanics, respectively. Intercalated in the amphibolites are several horizons of iron-formation. Oxide, carbonate, silicate and sulphide facies iron-formations are found as thin, discontinuous layers. In the extreme north-eastern part of the supracrustal belt a major low-grade iron ore deposite occurs. The most abundant sulphides in the supracrustal rocks are pyrite, pyrrhotite and copper sulphides, mainly chalcopyrite and cubanite (Appel, 1979). The iron-formation and the sulphide mineralisation are thought to be of submarine exhalative origin (Appel, 1979, 1980). After deposition the supracrustals suffered several phases of deformation and metamorphism. The highest grade of metamorphism obtained is amphibolite facies (Nutman et al., 1983).

In the Godthåb area, south-west of the Isua supracrustal belt, a large number of supracrustal enclaves, the so-called Akilia enclaves occur. These enclaves, which are of the same age and show the same lithology as the Isua supracrustal rocks, are believed to be remnants of a once much more extensive supracrustal belt. The Akilia enclaves range in size from a few metres long to several hundred metres in length, and contain small amounts of scheelite (Appel, 1983).

\section{Sampling programme}

Stream sediment samples were collected in streams which exclusively drain the supracrustal belt. At each sample site about 5 litres of coarse gravel and sand were collected and passed through a plastic sieve with $1 \mathrm{~mm}$ holes. The coarse fraction, which constitutes the main part of the samples, was discarded, and the fine fraction was panned and inspected in ultra-violet light, to count the amount of scheelite grains. 


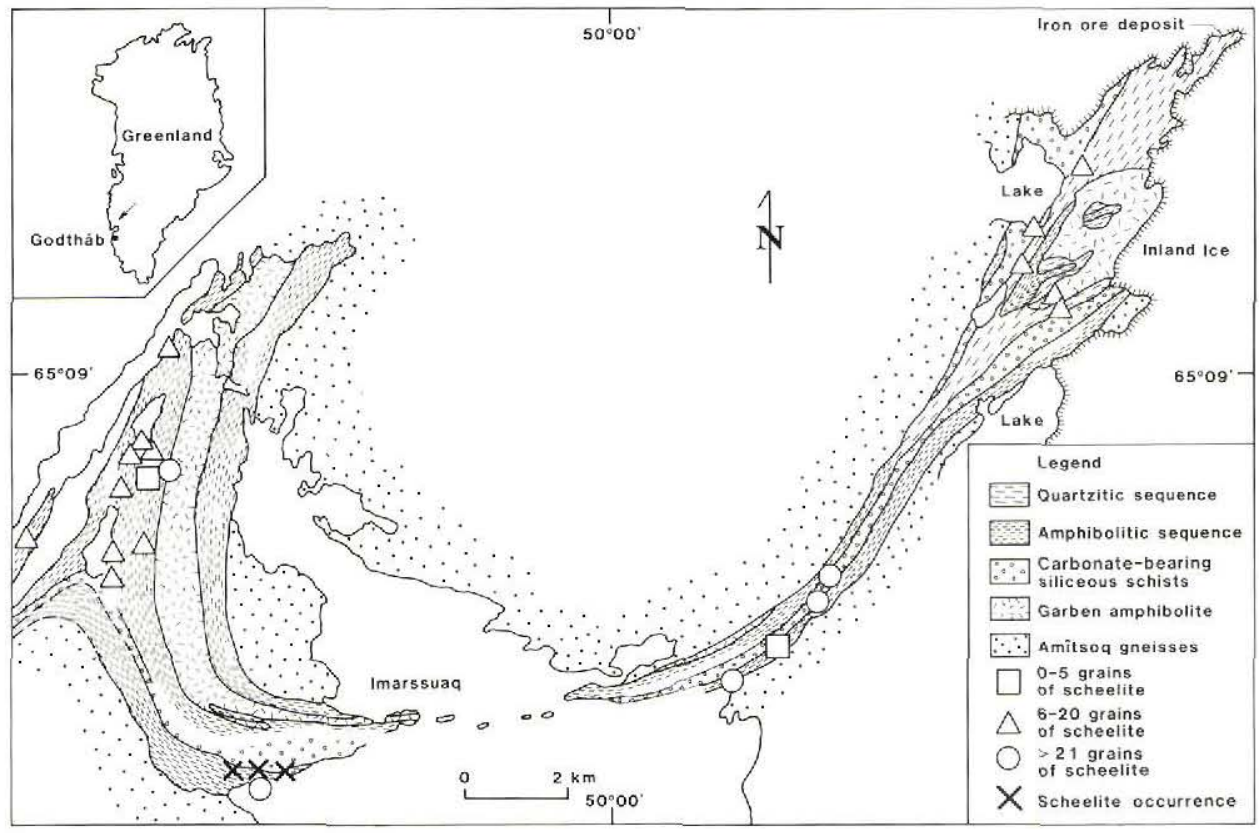

Fig. 16. Geological sketch map of the Isua supracrustal belt at Isukasia, West Greenland (modified from Allaart, 1976).

The results are shown in fig. 16 , where the most anomalous samples contain more than 21 grains of scheelite per 5 litres of stream sediment. Previous field work has shown that wellmineralised zones only shed very few grains of scheelite in the drainage (Appel, 1984). Thus the anomalies in the Isukasia area could indicate highly mineralised zones.

The distribution of scheelite in the stream sediments indicates that most of the scheelite occurrences are probably hosted in the amphibolitic sequence. An exception is the sample collected in the extreme north-eastern part of the supracrustal belt, which seems to indicate scheelite occurrences in the quartzitic sequence. However, this stream also drains the area covered by the Inland Ice south of the iron ore deposit, thus indicating the presence of supracrustal amphibolites hidden by the Inland Ice.

\section{Scheelite occurrences}

Owing to the limited amount of time available, prospecting for in situ scheelite could only be carried out in a small area. One of the most anomalous streams with 47 grains of scheelite in 5 litres of stream sediment was chosen for follow up work. This stream is situated in the southern periphery of the supracrustal belt where it traverses the amphibolitic sequence (fig. 16).

In this area, the supracrustal rocks have steep dips and are tightly isoclinally folded. The most common rock type is a weakly-layered well-lineated, dark grey to black amphibolite which occurs in horizons up to $10 \mathrm{~m}$ wide. Intercalated in these amphibolites are thin $(<1 \mathrm{~m})$ 
horizons of metarhyolites, greenish well-layered calc-silicate rocks, and highly altered ultrabasic rocks. Scheelite has been found within all these rock types.

The most common occurrence of scheelite is in the layered amphibolites and in the calcsilicate rocks. It occurs as tiny disseminated grains partly arranged parallel to the layering and also as centimetre-size porphyroblasts, as joint coatings and in thin irregular stringers. The scheelite shows a bluish to bluish-white fluorescence. In the amphibolites the scheelite shows a tendency to occur in specific horizons of the order of one to a few metres in width. These horizons can be traced at intervals of a few hundred metres.

Metarhyolites, which are scarce in the amphibolitic sequence in this area, occur as layers up to one metre wide. Scheelite is not common in these acid volcanics, but does occur as scattered disseminated grains, usually with bluish-white fluorescence. In the altered ultrabasic rocks scheelite is very rare, but when seen it displays a white to yellowish-white fluorescence.

In the Isua supracrustal rocks several minor discordant quartz veins have been found, one of which contained a few tiny grains of bluish fluorescent scheelite.

The amount of scheelite in the Isukasia area is still not known. In the very limited field area investigated in 1984 scheelite is quite abundant, but nowhere approaches ore grade. The stream-sediment sampling clearly shows that scheelite must be quite abundant throughout the whole supracrustal belt.

Acknowledgements. The author is grateful to Charlotte Clausen for her valuable assistance in the field and to E. Leonardsen, Institute of Mineralogy, University of Copenhagen for X-ray determination of scheelite.

\section{References}

Allaart, J. H. 1976: The pre-3760 m.y. old supracrustal rocks of the Isua area, central West Greenland, and the associated occurrence of quartz-banded ironstone. In Windley, B. F. (edit.) The early history of the earth, 177-189. London: Wiley \& Sons.

Appel, P. W. U. 1979: Stratabound copper sulfides in a banded iron-formation and in basaltic tuffs in the early Precambrian Isua supracrustal belt, West Greenland Econ. Geol. 74, 45-52.

Appel, P. W. U. 1980: On the early Archaean Isua iron-formation, West Greenland. Precambrian Res. 11, 73-87.

Appel, P. W. U. 1983: Tungsten in the Godthåb area, West Greenland. Rapp. Grønlands geol. Unders. $115,59-63$.

Appel, P. W. U. 1984: Tungsten mineralisation in the Godthåb area, West Greenland. Rapp. Grønlands geol. Unders. 120, 51-54.

Nutman, A. P., Bridgwater, D., Dimroth, E., Gill, R. C. O. \& Rosing, M. 1983: Early (3700 Ma) Archaean rocks of the Isua supracrustal belt and adjacent gneisses. Rapp. Gronlands geol. Unders. 112, $5-22$. 